\title{
Analysis of the Effectiveness of Family Approach System Model as Efforts to Optimize Germas Program
}

Fauzie Rahman ${ }^{1 *}$, Vina Yulia Anhar ${ }^{2}$, Anggun Wulandari ${ }^{1}$, Nur Laily ${ }^{1}$, Ayu Riana Sari ${ }^{1}$, Nita Pujianti ${ }^{1}$, Lia Anggraini ${ }^{1}$, Agus Muhammad Ridwan ${ }^{3}$, Farid Ilham Muddin ${ }^{3}$, Muhammad Azmiyannoor ${ }^{4}$

${ }^{1}$ Health Administration Policy, Public Health Program Study, Faculty of Medicine, Lambung Mangkurat University, Banjarmasin, Indonesia; ${ }^{2}$ Health Promotion and Behavior, Public Health Program Study, Faculty of Medicine, Lambung Mangkurat University, Banjarmasin, Indonesia; ${ }^{3}$ College Student of Master of Public Health Program Study, Faculty of Medicine, Lambung Mangkurat University, Banjarmasin, Indonesia; ${ }^{4}$ College Student of Public Health Program Study, Faculty of Medicine, Lambung Mangkurat University, Banjarmasin, Indonesia

Edited by: Slavica Hristomanova-Mitkovska Citation: Rahman F, Anhar VY, Wulandari A, Laily N, ari AR, Pujianti N, Anggraini L, Ridwan AM, Muddin Fi, Azmiyannoor M. Analysis of the Effectiveness of Family Approach System Model as Eforts to Optimize Germas (E).307-311. htps/ldoi Keywords: Family approach system; Germes; Knowledge; Attitudes; Intention; Behavio "Corresponding author: Mr. Fauzie Rahman, Health ersity, Banjarmasin, Indonesi. -mail: fauzie21@ulm.ac. Received: 04-Mar-202 Revised: 31-Mar-2021 Accepted: 19-Apr-2021 Copyright: ๑ 2021 Fauzie Rahman, Vina Yulia Anhar Angun Wulandari, Nur Laily, Ayu Riana Sari, Nita Pujian Muddin Mumamman, Farid lhan Muddin, Muhammad Azmiyannoor Medicine, Lambung Mangkurat University
Competing Interest: The authors have declared that no competing interest exist Open Access: This is an open-access article distributed under the terms of the Creative Commons AttributionNonCommercial 4.0 International License (CC BY-NC 4.0)

\section{Abstract}

BACKGROUND: Family approach system (FAS) model is an approach to health education as efforts to optimize community movement healthy living (Germas) program days of the pandemic coronavirus disease 2019 (COVID- 19) which involved cadres.

AIM: This study generally aims to analyze the effect of FAS model as an effort to optimize the Germas program. Specifically, the specific objective of this study is to analyze the effect of FAS model on the level of knowledge attitudes, intentions, and public behavior regarding Germas.

MATERIALS AND METHODS: This research was conducted using a cross-sectional method with a total sample of 3.026 people. The instrument used was a questionnaire to measure the effectiveness of the FAS model, knowledge, attitudes, intentions, and behavior. The statistical test used is the Wilcoxon Signed Rank Test.

RESULTS: The increase which indicates the good category knowledge of the respondent is $97.4 \%$ with a value of $p=0.000$, a positive attitude has also increased to $90.4 \%$ with a value of $p=0.000$, and good intentions also have significant increase to $94.2 \%$ with $p=0.000$. The respondent's good behavior also experienced a significant increase to 87.0 with a value of $p=0.000$

CONCLUSIONS: There is an influence of the FAS model on people's knowledge, attitudes, intentions, and behavio regarding Germas during the COVID-19 pandemic.

\section{Introduction}

Indonesia as a member of the United Nations has participated in following up the global sustainable development goals (SDGs) policy by issuing Presidential Decree No.59 of 2017 concerning SDGs and its follow-ups. The SDGs are a continuation of the millennium development goals program which ended in 2015 [1], [2]. In this presidential decree, the government strives to end poverty, improve health public, promote education, and fight climate change. From several derivatives toward the achievement of the SDGs, there are important points of concern for improving health, namely SDGs point 2 to end hunger, 3 ensuring healthy living and supporting wellbeing for all ages, and 6 ensuring the availability and sustainable management of clean water and sanitation for all [3], [4]. The Minister of Health has compiled a Strategic Plan for the Ministry of Health for 2015-2019 by carrying out the Healthy Indonesia Program. Several agendas were coordinated down to the provincial level, including the Healthy Living Community Movement (Germas) [5].

The Germas program is a systematic and planned action carried out by all components of society with the awareness, willingness, and ability to behave in a healthy manner to improve the quality of life. The aim of this program is to reduce the number of diseases, reduce the burden on care costs health, increase population productivity, and reduce the financial burden on the community for expenditures health. The Germas program is carried out by each individual in the family in the community by practicing daily life patterns. In this program, the government acts as a provider of health services/facilities and infrastructure as well as mobilizing healthy community institutions and organizations. Germas aims to enable each individual in the family to do physical activity, eat vegetables and fruit, carry out regular health checks, not smoke and consume alcohol, clean the living environment, and use the latrine [5]. 
Along with the increase in mobility and lifestyle, the appearance of various diseases has also increased dramatically so that the cost of treatment is getting higher even though currently the government has helped a lot through the BPJS. The cost effect is believed to be one reason people are starting to become aware of the importance of health [6]. The Germas program which focuses on preventive efforts is considered to be very appropriate in responding to community needs to achieve health and welfare [7]. Germas activities that focus on preventive efforts require strengthening from various parties; otherwise, this program will quickly be forgotten. In this case, the Provincial Health Office, which is facilitated by the local government, coordinates with various crosssectoral activities in each program. Strengthening the program involves various facilities and infrastructure as well as existing resources in the community [6].

At present, the implementation of the Germas Program is still not running as expected, especially the difficulties at the monitoring and evaluation stages of the program. A program is of course inseparable from the existing constraints; therefore, it is important to conduct regular monitoring and evaluation. Monitoring can be done in various ways while the agenda is running to assess obstacles and constraints that may occur as an evaluation material [8]. There are several strategies that can be carried out in strengthening and strengthening Germas, including the modeling concept that involves the role of the community directly. This concept has begun to be applied in several regions in Indonesia. Among them is modeling with a family approach. Family is an important component in disease prevention efforts, in addition to the role of the quality of the environment and health facilities and infrastructure. Family is also the first place where children get their social life and education, including education related to health. Healthy living behavior that is obtained early on will trigger awareness of the importance of health both in the family and in the community [9]

If done consistently, this healthy behavior will persist and have a positive impact on society. With the increase status in public health, the value of productivity will increase and the quality will increase so that the welfare in all aspects of life will increase. Some household members have a period of vulnerability to infectious and non-infectious diseases, therefore to prevent this, household members need to be empowered to implement Germas. Germas can prevent individuals, groups, and communities from infectious and non-infectious diseases. However, if the application of Germas is still low, it will cause various diseases such as diarrhea, malnutrition, malnutrition, dengue fever, acute respiratory infection (ARI), and others which will cause a low degree of public health.

Based on the results of previous research, it is known that health cadres have an important role for the health centers in their working areas. The role of cadres has a role of $80 \%$ in the success of the PHBS program in household settings. The results above can be an innovation in implementing the Germas program. Based on the success of previous programs that have been carried out, an alternative solution that can be implemented in the field is by modeling the family approach system (FAS) as an effort strengthening of Germas in the community in the context of accelerating SDGs number 2, 3, and 6. With this modeling, it is hoped that it can increase awareness, willingness, and ability of the community to behave healthily in an effort to improve the quality of life, especially increasing community participation and participation for healthy living, increase community productivity, and reduce the burden of health costs.

\section{Materials and Methods}

This study generally aims to analyze the effect of the model FAS as an effort to optimize the Germas program. Specifically, the specific objective of this study is to analyze the effect of FAS model. The research focus is measuring the levels of knowledge, attitudes, intentions, and public behavior regarding Germas. This research was conducted using a cross-sectional method with a total sample of 3.026 people. The instrument used was a questionnaire to measure the effectiveness of the FAS model, knowledge, attitudes, intentions, and behavior. The statistical test used is the Wilcoxon Signed Rank Test.

\section{Results and Discussion}

The results of statistical tests conducted to determine the effect of the FAS model on public knowledge, attitudes, intentions, and behavior regarding Germas during the coronavirus disease 2019 (COVID19) pandemic (Table 1).

Table 1: Results of the influence of the FAS model toward knowledge, attitudes, intentions, and behavior regarding Germas during the COVID-19 pandemic

\begin{tabular}{|c|c|c|c|c|}
\hline \multirow[t]{2}{*}{ Variable } & \multicolumn{2}{|l|}{ Pre-test } & \multicolumn{2}{|l|}{ Post-test } \\
\hline & $n=3026$ & $\%$ & $n=3026$ & $\%$ \\
\hline \multicolumn{5}{|l|}{ Knowledge } \\
\hline Poor & 723 & 23.9 & 79 & 2.6 \\
\hline Good & 2303 & 76.1 & 2947 & 97.4 \\
\hline$p$-value & 0.000 & & & \\
\hline \multicolumn{5}{|l|}{ Attitudes } \\
\hline Negative & 673 & 22.2 & 289 & 9.6 \\
\hline Positive & 2353 & 77.8 & 2737 & 90.4 \\
\hline$p$-value & 0,000 & & & \\
\hline \multicolumn{5}{|l|}{ Intention } \\
\hline Poor & 678 & 22.4 & 175 & 5.8 \\
\hline Good & 2348 & 77.6 & 2851 & 94.2 \\
\hline $\mathrm{p}$-value & 0,000 & & & \\
\hline \multicolumn{5}{|l|}{ Behavior } \\
\hline Poor & 745 & 24.6 & 392 & 13.0 \\
\hline Good & 2281 & 75.4 & 2634 & 87.0 \\
\hline$p$-value & 0,000 & & & \\
\hline
\end{tabular}

Table 1 shows that the increase which indicates the good category knowledge of the respondent is 
$97.4 \%$ with a value of $p=0.000$, a positive attitude has also increased to $90.4 \%$ with a value of $p=0.000$, and good intentions also have a significant increase to $94.2 \%$ with $p=0.000$. The respondent's good behavior also experienced a significant increase to 87.0 with a value of $p=0.000$. Thus, the FAS Model is able to improve respondents' knowledge, attitudes, intentions, and behavior in a better and more positive direction.

FAS model is an approach to health education as an effort to optimize the Healthy Living Society Movement (Germas) program during the COVID-19 pandemic which was carried out by involving cadres. The existence of health cadres as Family Support is one of the reinforcing factors that can influence positive behavior [10], [11]. Cadres are tasked with providing online counseling with a direct approach to targeted households to explain the Healthy Living Community Movement (Germas) during the COVID-19 pandemic. The information provided by the cadres to the targeted households, namely: (1) Definition of the Healthy Living Community Movement (Germas); (2) the objectives of Germas; (3) the seven steps for implementing Germas and examples of their application, namely: (1) Perform physical activity; (2) routinely consume fruits and vegetables; (3) no smoking; (4) does not consume alcoholic beverages; (5) do periodic health checks; (6) maintain environmental cleanliness; and (7) using latrines.

\section{As well as additional sub-material regarding important reasons Germas needs to be applied during the COVID-19 pandemic}

Counseling is a process of providing objective and complete information, carried out systematically with guidance on interpersonal communication skills, guidance techniques, and mastery of clinical knowledge, aims to help a person recognize their current condition, the problem at hand and determine solutions or efforts to overcome these problems [12]. Counseling is essentially a method of extension. Counseling is essentially an activity to convey health messages to the community, groups, or individuals [13]. The existence of this message, society, groups, or individuals can gain knowledge about better health. In this study, the purpose of counseling is to help the community who become respondents understand the concept of Germas so that they are aware and want to apply Germas in their daily lives. Good counseling will increase the knowledge, awareness, intention, and behavior of the community regarding Germas.

Quality interactions between cadres and the community who are respondents in this study are one of the most decisive indicators for the success of the FAS model intervention. The success of the FAS model can be seen from the increasing public knowledge of knowledge, attitudes, intentions, and behavior regarding Germas during the COVID-19 pandemic. Based on Table 1, it can be seen that there is a difference in knowledge between the knowledge before the intervention with the
FAS model and the knowledge after intervention with the FAS model. Hence, it can be concluded that there is an influence of the FAS model on public knowledge about Germas during the COVID-19 pandemic. These results show the success of the FAS model in increasing public knowledge about the meaning of Germas, the objectives of Germas, the benefits of physical activity which is part of Germas, the impact of eating less vegetables and fruit, the minimum duration of physical activity, the frequency of carrying out health checks in 1 year, the benefits if you stop/do not consume alcohol, and the benefits of using a healthy toilet/latrine. The results of this study are in line with research conducted by Sofiyana and Noer (2013), which states that counseling can increase maternal knowledge about feeding malnourished children [14]. Based on Räsänen et al. (2004), a relatively short counseling process can increase knowledge that needs to be elaborated [15]. Knowledge is the result of knowing someone about an object through the senses that are owned and influenced by attention and perception of the object. Knowledge of environmental health can be the basis for people to behave well [16].

There is an influence of the FAS model on people's attitudes about Germas during the COVID-19 pandemic. These results indicate the success of the FAS model to improve community attitudes regarding support for the Germas program, the importance of implementing Germas in daily life, the importance of physical activity, consuming fruits and vegetables, routine health checks, avoiding smoking habits, the impact of alcohol on social life, damaging the body and can cause various kinds of diseases, the belief is that if you are diligent in maintaining a clean environment, you will avoid diseases caused by an unhealthy environment such as fever, diarrhea, dysentery, and respiratory diseases, worry that if you do not use a healthy latrine, you will be infected with a virus or disease bacteria, the understanding that if the Germas program is implemented in everyday life, it will be able to reduce the burden of disease, including COVID-19 and reduce the cost of health services, the belief that following the information/advice provided by health workers can help reduce the risk of disease. Enablement of COVID-19, concern that COVID-19 can be transmitted through food consumed, concern that COVID-19 can be transmitted through droplets from the respiratory tract.

These results also show the success of the FAS model to improve people's attitudes about COVID-19 which can cause serious illness and death, the symptoms of COVID-19 are the same as flu in general, and the importance of washing hands can help reduce the risk of getting infected with COVID-19 using water. Clean flowing and soap, the importance of using a mask wherever properly can help reduce the risk of being infected with COVID-19, the importance of cloth masks that need to be cleaned properly regularly, the belief that smoking contributes to the transmission of COVID-19, the belief that eating a balanced nutritious diet can help increase body immunity and reduce the risk of being infected with COVID-19, the belief by exercising 
at least 30 min every day can help improve body fitness in preventing transmission of COVID-19, the belief that maintaining a minimum distance of $1 \mathrm{~m}$ can help reduce the risk of transmission COVID-19, feels it is important when coughing or sneezing, no need to cover your mouth, and you need to take a shower immediately when you get home after doing activities outside the home.

This research is in line with research conducted by Sofiyana and Noer (2013) which states that counseling can increase maternal knowledge about feeding malnourished toddlers [14]. Attitude is a person's willingness to act or respond to stimuli from an object of stimulation [13]. A good subject's attitude toward environmental health will influence good behavior about environmental health. Through counseling, individuals get information about environmental health that can be related to disease incidence, this information is useful for consideration in attitude and after being positive, the individual responds by deciding to take action. In their research, Schlair et al. (2012) stated that counseling can increase subject knowledge and affect attitudes to be more positive. Counseling has proven to be effective in changing better attitudes about environmental health [17].

There is a difference in intention between the intention before the intervention with the FAS model and the intention after the intervention with the FAS model. Hence, it can be concluded that there is an influence of the FAS model on people's intentions regarding Germas during the COVID-19 pandemic. According to Albery and Munafo (2011), this intention is determined to what extent individuals choose to carry out certain behaviors and receive support from influential others [18]. These results show the success of the FAS model to increase people's intention of wanting to do physical exercise every week, consume vegetables and fruits every day, carry out regular periodic health checks, will not smoke and consume alcohol, maintain the cleanliness of the surrounding environment to avoid. From various health problems, defecating in latrines on the banks of rivers, the desire to use clean water for all daily needs, applying Germas in daily life, applying information/advice provided by health workers to reduce the risk of COVID-19 transmission, washing hands frequently using clean running water and soap to reduce the risk of contracting COVID-19, the desire not to use a mask anywhere properly to reduce the risk of COVID-19 transmission, clean cloth masks properly regularly, smoke to reduce the risk of COVID-19 transmission -19, eating a balanced nutritious diet to reduce the risk of COVID-19 transmission, exercising to reduce the risk of transmission of COVID-19, maintaining a minimum distance of $1 \mathrm{~m}$ with anyone to reduce the risk of transmitting COVID19, covering the mouth with a tissue/elbow when coughing and sneezing, and the desire to take a shower right away when you get home after doing your activities outside.

There is a difference in behavior between the behavior before the intervention with the FAS model and the behavior after the intervention with the FAS model. Hence, it can be concluded that there is an influence of the FAS model on people's behavior regarding Germas during the COVID-19 pandemic. These results show the success of the FAS model in improving community behavior regarding the importance of physical exercise for $30 \mathrm{~min}$ every day, eating a nutritionally balanced diet, consuming $1 / 2$ plate of fruit and vegetables, and $1 / 2$ plate of side dishes and staple foods, regular health checks, not smoking. And consuming alcohol, routinely cleaning the surrounding environment to avoid various health problems, utilizing healthy latrines for defecating, using clean water for all daily needs, applying Germas in daily life, applying information/advice given by health workers for reducing the risk of COVID-19 transmission, washing hands frequently using clean running water and soap to reduce the risk of transmission of COVID19, using masks wherever appropriate to reduce the risk of transmission of COVID-19, cleaning cloth masks properly regularly, smoking to reduce risks COVID-19 protection, eating a balanced nutritious diet to reduce the risk of COVID-19 transmission, exercising to reduce the risk of COVID-19 transmission, maintaining a minimum distance of $1 \mathrm{~m}$ with anyone to reduce the risk of COVID-19 transmission, not covering your mouth with a tissue/elbow when coughing and sneezing, and immediately take a shower when you get home after doing activities outside the house.

According to Widodo and Susilo (2020), Germas behavior is an effort to increase awareness, willingness, and ability of the community to behave healthily in an effort to improve the quality of life [19]. In essence, health development is an effort carried out by all components of the Indonesian nation which aims to increase awareness, ability, and ability to live a healthy life for everyone to realize the highest public health status [20], [21].

Currently, Indonesia is experiencing a change in disease patterns, which is often referred to as an epidemiological transition, which is marked by an increase in mortality and illness due to noncommunicable diseases (PTM) such as stroke, heart disease, diabetes, and others. The impact of the increasing incidence of PTM is the increase in health service financing that must be borne by the community and government; decreased productivity of society; decreasing state competitiveness which in turn affects the socioeconomic conditions of the community itself.

\section{Conclusions}

The model FAS is an approach to health education as an effort to optimize the Healthy Living Community Movement (Germas) program during the COVID-19 pandemic which was carried out by 
involving cadres. The existence of health cadres as Family Support is one of the reinforcing factors that can influence positive behavior. The results of statistical tests show that there are differences in knowledge, attitudes, intentions, and behaviors before and after the intervention with the FAS model.

\section{References}

1. Kumar S, Kumar N, Vivekadhish S. Millennium development goals (MDGs) to sustainable development goals (SDGs): Addressing unfinished Agenda and strengthening sustainable development and partnership. Indian J Community Med. 2016;41(1):1-4. https://doi.org/10.4103/0970-0218.170955 PMid:26917865

2. World Health Organization. World Health Statistics 2016: Monitoring Health for the SDGs Sustainable Development Goals. Geneva: World Health Organization; 2016. https://doi. org/10.26719/2016.22.5.350

3. Aida PM. Analisis Pelaksanaan Gerakan Masyarakat Hidup Sehat di Wilayah Kerja Puskesmas Susoh Kabupaten Aceh Barat Daya Tahun 2019, Thesis; 2020. https://doi.org/10.20527/ jpkmi.v5i1.4999

4. World Health Organization. Health in 2015: From MDGs, Millennium Development Goals to SDGs, Sustainable Development Goals. Geneva: World Health Organization; 2015. https://doi.org/10.1111/padr.12006

5. Kementerian Kesehatan Republik Indonesia. Buku Panduan GERMAS (Gerakan Masyarakat Hidup Sehat), War. Kesmas. Indonesia: Kementerian Kesehatan Republik Indonesia; 2017. https://doi.org/10.21109/kesmas.v9i3.568

6. Ladia SM. Optimization of the Germas Program. Serambi Mekkah University USM Faculty of Public Health; 2017.

7. Batoebara MU, Junaidi J. Perencanaan Komunikasi Fasilitator Kesehatan Dalam Program Gerakan Masyarakat Hidup Sehat (GERMAS). War Dharmawangsa; 2018. https://doi. org/10.31506/jsc.v1i1.7765

8. Cahyani DI, Kartasurya MI, Rahfiludin MZ. Gerakan masyarakat hidup sehat dalam perspektif implementasi kebijakan (Studi Kualitatif). J Kesehat Masy Indones 2020;15(1):1-18. https://doi. org/10.26714/jkmi.15.1.2020.10-18

9. Rahmawaty E, Handayani S, Sari MH, Rahmawati I. Sosialisasi Dan Harmonisasi Gerakan Masyarakat Hidup Sehat (GERMAS)
Dan Program Indonesia Sehat Dengan Pendekatan Keluarga (PIS-PK) Di Kota Sukabumi. Vol. 15. LINK; 2019. https://doi. org/10.31983/link.v15i1.4385

10. Notoatmodjo S. Pengantar Pendidikan. Kesehatan dan IImu Perilaku Kesehatan. Yogyakarta; Andi Offset; 1997.

11. Haryuni H. Hubungan Antara kemampuan Dan Motivasi Kader Dengan Penampilan Kerja Kader Pusyandu, Medan; 1997.

12. Herman. Peran Konselor Dalam Membantu Proses Penyembuhan Remaja Pengguna Narkoba Melalui Pendekatan Bimbingan Konseling Di Badan Narkotika Nasional Provinsi Jambi. Jambi: Fakultas Dakwah Universitas Islam Negeri Sultan Thaha Saifuddin; 2019. https://doi.org/10.18202/ jamal.2019.08.10019

13. Notoatmodjo S. Health Education and Behavior. Jakarta: Rineka Cipta; 2003.

14. Sofiyana D, and Noer ER. Perbedaan pengetahuan, sikap dan perilaku ibu sebelum dan setelah konseling gizi pada balita gizi buruk. J Nutr Coll 2013;2:1. https://doi.org/10.14710/jnc. v2i1.2109

15. Räsänen $M$, Niinikoski $H$, Keskinen $S$, Heino $T$, Lagström $H$, Simell $O$, et al. Impact of nutrition counselling on nutrition knowledge and nutrient intake of 7- to 9-y-old children in an atherosclerosis prevention project. Eur $\mathrm{J}$ Clin Nutr 2004;58(1):162-72. https://doi.org/10.1038/sj.ejcn.1601763 PMid: 14679382

16. Notoatmodjo S. Promosi Kesehatan Teori dan Aplikasi. Jakarta: Rineka Cipta; 2005. p. 52-4.

17. Schlair S, Hanley K, Gillespie C, Disney L, Kalet A, Darby PC, et al. How medical students' behaviors and attitudes affect the impact of a brief curriculum on nutrition counseling. $J$ Nutr Educ Behav 2012;44:653-7. https://doi.org/10.1016/j. jneb.2011.08.006

18. Albery IP, Munafo M. Psikologi Kesehatan, Panduan Lengkap dan Komprehensif Bagi Studi Psikologi Kesehatan. Mitra Setia; 2011.

19. Widodo T, Susilo C. Pengaruh Tingkat Pengetahuan Phbs Dengan Perilaku Germas Mahasiswa Poltekkes Kemenkes Palangka Raya. J Kedokt 2020;8:1.

20. Nofriani M. Faktor-Faktor Yang Berhubungan Dengan Penerapan Phbs Di Tatanan Rumah Tangga Di Wilayah Kerja Puskesmas IV Koto Mudik Kecamatan Batang Kapas Kabupaten Pesisir Selatan Tahun 2016, Diploma, Universitas Andalas; 2016. https://doi.org/10.20527/jpkmi.v5i1.4999

21. Salem P, Sandler I, Wolchik S. Taking stock of parent education in the family courts: Envisioning a public health approach. Fam Court Rev 2013;51:131-48. https://doi.org/10.1111/fcre.12014 PMid:23641191 